\title{
Unusual breeding of the Grey Heron (Ardea cinerea) and Crested Tit (Lophophanes cristatus) in urban environment
}

\author{
Neobvyklé hniezdenie volavky popolavej (Ardea cinerea) a sýkorky \\ chochlatej (Lophophanes cristatus) v mestskom prostredi
}

\section{Nina Babicová ${ }^{1}$, Jana PAVLíková ${ }^{2}$, Ružena BABICová ${ }^{1}$ \& Anton KRIŠTín ${ }^{3}$}

\author{
${ }^{1}$ Prachatická 29, SK-960 53 Zvolen, Slovakia \\ ${ }^{2}$ Očovská cesta 14, SK-960 01 Zvolenská Slatina, Slovakia \\ ${ }^{3}$ Institute of Forest Ecology SAS, L. Štúra 2, SK-960 53 Zvolen, Slovakia; e-mail: kristin@ife.sk
}

\begin{abstract}
Urbanization changes natural environments by transforming the landscape and reducing local biodiversity. However, some urban areas with heterogenous habitats can represent a supplementary breeding environment for non-urban birds. Successful and unusual breeding of Grey Heron (Ardea cinerea) and Crested Tit (Lophophanes cristatus) was found in Zvolen city (C Slovakia). Three pairs of Grey Heron bred successfully in trees in the green fragment of abandoned riparian vegetation in the old bed of Slatina river, nearby Zvolen castle in city center in 2020 and 2021. The mean start of breeding was delayed by three weeks in comparison to known data from former Czechoslovakia. Furthermore, breeding of the Crested Tit was documented in the cavity of a panel house insulation. Five chicks fledged on May 10, a little bit earlier than the known fledging period in Central Europe. Position of nests, breeding success and phenology is described and discussed for both species.
\end{abstract}

Key words: urbanization, birds, urban greenery, building, cavities

Urbanization is an expanding process worldwide. It changes natural environments by transforming the landscape and mostly drastically reducing local biodiversity (Filloy et al. 2019). For several bird species, some urban areas with heterogenous green habitats can represent suitable environment for life and even enable them to maintain stable and abundant populations (Luniak 1981, Tryjanowski et al. 2017). Buildings and urban greenery are crucial elements for bird breeding in cities, with an increased proportion of urban woody greenery increasing species diversity and abundance (Jokimäki et al. 2016). Birds respond to urbanization through the infiltration of "non-urban" species into the city, changed behavior, and increased adaptability to the urban environment
(Morelli et al. 2019). Forest bird species (nesting primarily in the forest) use both urban woody greenery (parks, cemeteries, orchards, gardens, alleys and other similar habitats; Tryjanowski et al. 2017) as well as human buildings for breeding (Cramp 1986, Jokimäki et al. 2016, Janus \& Lesinski 2018). Even several waterbird species can breed in an urban environment if cities have such habitats.

The Grey Heron (Ardea cinerea) is the species breeding primarily on trees and in forests around streams and stagnant waters (Cramp 1986, Hudec 1994). Breeding has only been rarely documented on human buildings, e.g. on old bridges and building walls (Glutz 1993, Cramp 1986), or hunter high seat in reedbeds (Česák 2001). Nesting in the city center is not 
known to us from the literature. The species shows a positive population trend in Central Europe, which is also reflected in the positive range trend and through occupation of new habitats (Keller et al. 2020).

In 2020 and 2021, we found a breeding of this species in the Zvolen city center (central Slovakia). The site is located in a fragment of abandoned woody greenery around a small remnant of the old Slatina river bed (about $1.4 \mathrm{ha}$ ), less than $100 \mathrm{~m}$ east of Zvolen Castle, $30 \mathrm{~m}$ from a busy railway line, about $170 \mathrm{~m}$ SE of Zvolen's main square, about $320 \mathrm{~m}$ from today's river Slatina and $1300 \mathrm{~m}$ from the river Hron (48.5732914 N, 19.1292625 E, 290 m a.s.1., Fig. 1a). The site was originated at the end of the $19^{\text {th }}$ century by regulating the river Slatina (A. Vágner in verb.). Breeding of the species around the city has been known at least since 1950, in an oak forest near the Slatina river near Môt'ová (Hell \& Sládek 1963). Currently, the nearest breeding in this area is known in the steep beech forest near the Môt'ová water reservoir (4 km SE, 3-11 nests in 2017-2021) and in the riparian willow-alder vegetation of the Hron river near the Budča village $(5 \mathrm{~km} \mathrm{SW}$, 26-44 nests in 2017-2021).

In 2020, three pairs bred at the site in the Zvolen city center, all broods were successful. The nests were located on top of trees (twice willow Salix fragilis, once dead pear Pyrus communis, Fig. 1b and 1c), which grew scattered on the abandoned area of the fragment of riparian vegetation. The height of the nests was 8,10 and $11 \mathrm{~m}$, the southernmost and highest situated nest was on a willow above the surface of a small water plot (about $50 \times 10 \mathrm{~m}$ ). The remaining nests were built in willow and pear above ruderalized dense willow-poplar-mapple vegetation (their distance from the previous nest was 40 and $70 \mathrm{~m}$ to the north, Fig. 1). The first eggs in the nests were laid about April 25, 2020 (after recalculation of the incubation period 31-32 days and care of young 42-49 days; Št'astný
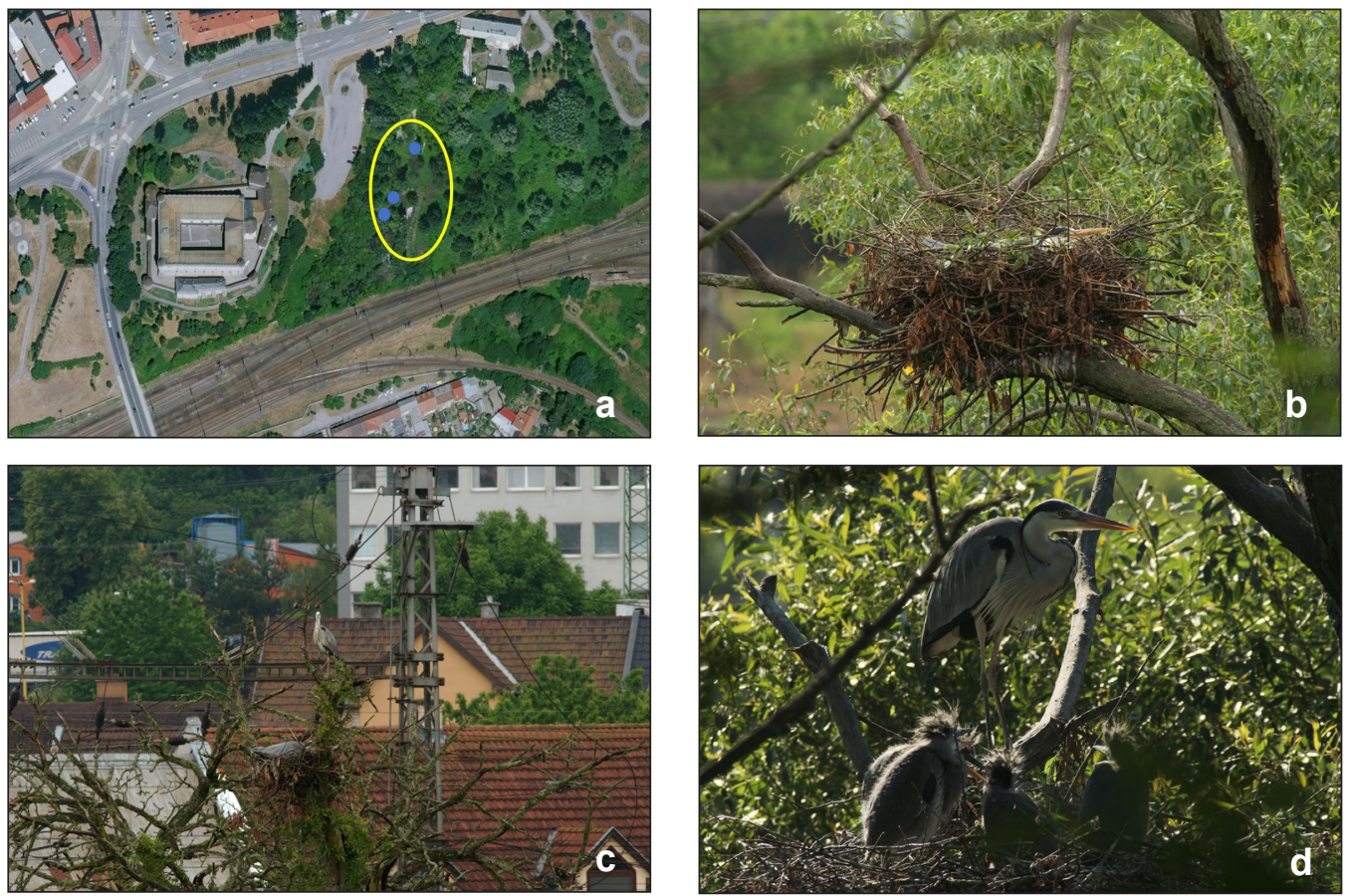

Fig. 1. Breeding of Grey Heron (Ardea cinerea) in Zvolen city centre. a) nest group position in 2020 (www.mapy.cz), b) nest in willow tree, c) nest in dead pear tree (10.6.2020), d) 35 days old chicks (July 5, 2020) (photo by Olaf Matthes).

Obr. 1. Hniezdenie volavky popolavej (Ardea cinerea) v centre mesta Zvolen. a) lokalizácia skupiny hniezd v r. 2020 (www.mapy. cz), b) hniezdo na vŕbe, c) hniezdo na suchej hruške (10. 6. 2020), d) mlád’atá vo veku asi 35 dní (5. 7. 2020) (foto: Olaf Matthes). 
\& Hudec 2011). The number of eggs remained unknown, because the nests were checked only from the ground. On June 10, 2020, there were small chicks (number unknown) aged up to about 10 days in the particular nests, while the adults were still brooding them. During further inspections (June 21, 29, July 10, 19, 25), we found maximum 3, 3 and 4 young in individual nests from a distance ca $30-40 \mathrm{~m}$. All three nests were successful, when the last chicks left the nests and the site on July 20-30, 2020, but the number of fledged chicks left unknown. No dead chicks were found in the vicinity of nests.

In 2021, three pairs bred again, but only two of them were successful. Two nests were this time on one, the southernmost localized tree (willow, 11 and $9 \mathrm{~m}$ high, about $4 \mathrm{~m}$ apart) above the water and the third was on a willow (9 m) $40 \mathrm{~m}$ north of the previous ones. The nest on the dead pear from the previous year has disappeared. There were four young on one nest, which could be checked (about 25 days old, June 25, 2021) and at least three young fledged around July 21, 2021. The birds start to build nests, resp. repaired them during March, but the first eggs were laid similarly to the previous year, at the end of April, i.e. about a month later than the average start of breeding of the species in former Czechoslovakia (Hudec 1994).

The Crested Tit (Lophophanes cristatus) is a typical breeding species of coniferous forests and, less in mixed forests (Glutz 1993). It is breeding mainly in tree cavities (87\%) and nest boxes (13\%, n = 55; Št'astný \& Hudec 2011). Nesting in tree cavities in cities is known in parks and urban greenery, if the cities are surrounded by coniferous forests. The species density increased westward in Europe in the Warsaw-Berlin-Hamburg gradient (Witt et al. 2005). Nesting in the cavities of buildings is not
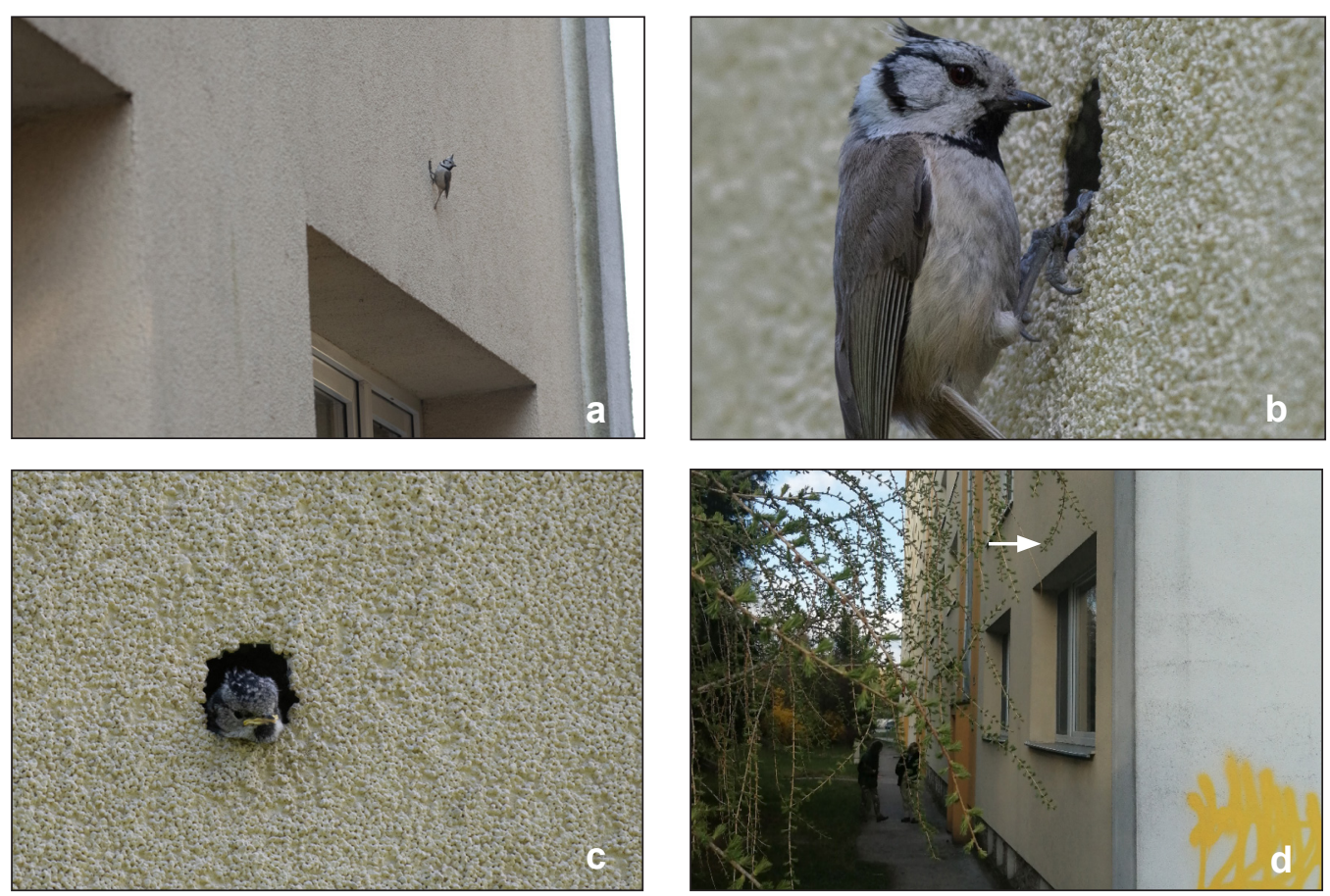

Fig. 2. Breeding of Crested Tit (Lophophanes cristatus) in building cavity in Zvolen. a) male, b) female (both photos: March 26, 2021), c) young just before fledging (May 10, 2021), d) position of breeding cavity shown by arrow (April 23, 2021) (photos by Nina Babicová).

Obr. 2. Hniezdenie sýkorky chochlatej (Lophophanes cristatus) v dutine panelového domu vo Zvolene. a) samec, b) samica (obe foto: 26. 3. 2021), c) mlád’a tesne pred vyletením z dutiny (10. 5. 2021), d) lokalizácia hniezdnej dutiny (šípka, 23.4. 2021) (foto: Nina Babicová). 
yet known from the literature (Glutz 1993, 1.c.). In the Zvolen area, the species is breeding in the surrounding coniferous and mixed forests and parks, e.g. in Sliač (own unpublished data) and in the Borová Hora Arboretum in coniferous stands and nest boxes (Ježovič \& Krištín 2007).

In 2021, we found a successful breeding in the cavity of a panel house insulation (polystyrene) in Zvolen (Zlatý Potok housing estate, ca. 6000 inhabitants/20 ha, $48.57873 \mathrm{~N}$, 19.15356 E, $333 \mathrm{~m}$ a.s.1.). The cavity (with NW exposition) was created probably by a woodpecker. The species occurs year-round in the locality with related species (Parus major, Cyanistes caeruleus, Periparus ater and Poecile palustris), but its nesting has not yet been confirmed. The housing estate was built about 45 years ago and has a relatively well-developed woody vegetation. The nest cavity was located at a height of $340 \mathrm{~cm}$ (ca. $20 \mathrm{~cm}$ above the ground floor window, Fig. 2a, d), 3-10 m from the group of coniferous trees ( 3 larches, 1 spruce and 1 pine), the trees being aged about 30-40 years, height $20 \mathrm{~m}$, but there are no tree cavities in the park for cavity breeding birds. The nest site is about $2 \mathrm{~km}$ south of the nearest forest. The pair built the nest in the cavity for several days from about March 26, 2021 (Fig. 2a, b), as the nest material was used moss, collected by the parents about 20-30 $\mathrm{m}$ from the nest. At least 5 chicks fledged on May 10, 2021 (Fig. 2c), what is a relatively early date compared to known data from the literature (Glutz 1993, Št'astný \& Hudec 2011). In the next three days the young and adults were observed in the nest vicinity up to $50 \mathrm{~m}$. If we calculate that the incubation period lasts 13-18 days and the parental care 17-21 days (Št’astný \& Hudec 2011), then the date of laying the first egg was around April 6 , and the young hatched from about April 22, 2021. Regarding the nest position, the average height of the nest in the former Czechoslovakia was $1.9 \mathrm{~m}$ and the average number of fledglings 5.13 (Št'astný \& Hudec 2011).

Successful breeding of both mentioned bird species suggest about diversity of habitats within and around the city of Zvolen, within the forests and mountains, and at the confluence of the rivers Hron and Slatina. Furthermore, it shows that there are heterogeneous habitats that allow breeding of these species in the urban environment (Callaghan et al. 2018).

\section{Acknowledgements}

We thank Olaf Matthes for documentation of Grey Heron breeding. The study was partially supported by VEGA grant No. 2/0065/20.

\section{References}

Callaghan C. T., Major R. E., Cornwell W. K., Poore A. G. B, Wilshire J. H. \& Lyons M. B. 2018: The effects of local and landscape habitat attributes on bird diversity in urban greenspaces. - Ecosphere 9: e02347.

Cramp S. (ed.) 1986: The birds of the Western Palearctic. Volume I. Ostrich to ducks. - Oxford University Press, New York.

ČESÁK J. 2001: Ptactvo přírodní rezervace Baroch a jeho okolí. - Panurus 11: 31-68.

Filloy J., Zurita G. A. \& Belloce M. I. 2019: Bird diversity in urban ecosystems: the role of the biome and land use along land use urbanization gradients. - Ecosystems 22: 213-227.

Glutz von Blotzheim U. 1993: Handbuch der Vögel Mitteleuropas 13/I, Passeriformes. - Aula Verlag, Wiesbaden.

Hell P. \& SlÁDeK J. 1963: Rozšírenie volavky popolavej (Ardea cinerea L.) na Slovensku. - Sborník Východoslovenského múzea 4: 77-91.

Hudec K. (ed.) 1994: Fauna ČR a SR, Ptáci 1. — Academia, Praha.

JANUS K. \& LesinsKi G. 2018: Birds and bats using buildings as a place of breeding or shelter. - Annals of Warsaw University of Life Sciences. Animal Science 57 (1): 19-29.

Ježovič V. \& KrišTín A. 2007: Vtáctvo Arboréta Borová hora (stredné Slovensko). — Tichodroma 19: 49-58.

JOKIMÄKI J., SUHONEN J., JoKIMÄKI-KAISANLAhti M. L.\& CARBÓ-RAmírez P. 2016: Effects of urbanization on breeding birds in European towns: impacts of species traits. — Urban Ecosystems 19: 1565-1577.

Keller V., Herrando S., Voríšek P., Franch M., Kipson M., Milanesi P., Martí D., Anton M., Klvañová A., Kalyakin M. V., Bauer H-G. \& Foppen R. P. B. 2020: European Breeding Bird Atlas: Distribution, 
Abundance and Change. - European Bird Census Council \& Lynx Edicions, Barcelona.

LUNIAK M. 1981: The birds of the park habitats in Warsaw. — Acta Ornithologica 18: 335-370.

Morelli F., Mikula P., Benedetti Y., Bussière R., JeRZAK, L.\& TRYJANOWSKI, P. 2018. Escape behaviour of birds in urban parks and cemeteries across Europe: Evidence of behavioural adaptation to human activity. - Science of Total Environment 631-632: 803-810. ŠŤastný K. \& Hudec K. (eds.) 2011: Fauna ČR, Ptáci 3/ II. - Academia, Praha.
Tryjanowski P., Morelli F., Mikula P., Krištín A., Indykiewicz P., Grzywaczewski P., Kronenberg J. \& JERZAK L. 2017: Bird diversity in urban green space: a large-scale analysis of differences between parks and cemeteries in Central Europe. - Urban Forestry \& Urban Greening 27: 264-271.

Witt K., Mitschke A. \& Luniak M. 2005: A comparison of common bird populations in Hamburg, Berlin and Warsaw. - Acta Ornithologica 40: 139-146.

Received: 24. 11. 2021

Accepted: 4. 1. 2022

Online: 24. 1. 2022 